placebo. The reverse occurred in one patient, who had a single episode with methenamine hippurate but was otherwise free of infection. The Wilcoxon matched pairs rank sum test gave a significant result $(\mathbf{p}<0.01)$.

Out of five relapses, four occurred while patients were taking placebo. Most infections were due to Escherichia coli (table). There was no difference between patients taking extra fluid and those with a normal fluid intake (28 versus 24 attacks), and extra fluid did not reduce the efficacy of methenamine hippurate (six versus five attacks). There were no signs of a carryover effect, and 23 episodes occurred in the first year versus 29 in the second year.

Organisms causing acute cystitis during study

\begin{tabular}{|c|c|c|c|c|c|}
\hline $\begin{array}{c}\text { Drug } \\
\text { treatment }\end{array}$ & $\begin{array}{c}\text { Total No of } \\
\text { cases of cystitis }\end{array}$ & $\begin{array}{l}\text { No of cases during } \\
\text { extra fluid intake }\end{array}$ & & \multicolumn{2}{|c|}{$\begin{array}{l}\text { No of cases during } \\
\text { ordinary fluid intake }\end{array}$} \\
\hline Placebo & 41 & 22 & & 19 & \\
\hline & & $\begin{array}{l}\text { (E coli } \\
\text { Klebsiella } \\
\text { Proteus mirabilis } \\
\text { unknown }\end{array}$ & $\begin{array}{l}15 \\
3 \\
3 \\
1)\end{array}$ & $\begin{array}{l}\text { E coli } \\
\text { Klebsiella } \\
\text { Proteus mirabilis } \\
\text { Enterobacter } \\
\text { Enterococci }\end{array}$ & $\begin{array}{l}11, \\
3, \\
1, \\
1, \\
3)\end{array}$ \\
\hline Methenamine hippurate & 11 & $\begin{array}{l}\text { E coli } \\
\text { Proteus mirabilis } \\
\text { Streptococcus group B } \\
\text { unknown }\end{array}$ & $\begin{array}{l}3, \\
1, \\
1 \\
1)\end{array}$ & $\left(E\right.$ coli ${ }^{5}$ & 5) \\
\hline
\end{tabular}

\section{Discussion}

We found $2 \cdot 1$ infections per patient/year with placebo but only 0.8 with methenamine hippurate $(\mathrm{p}<0.01)$. These figures are better than those reported after administration of $2 \mathrm{~g}$ methenamine mandelate together with $2 \mathrm{~g}$ ascorbic acid, indicating that ascorbic acid is unnecessary.

Because methenamine hippurate is well tolerated, is effective, and fails to produce cross resistance to conventional antibiotics it seems to be a suitable prophylactic agent against recurrent acute cystitis in women.

We thank Mr Ulf Parkhede and Mrs Margareta Gunolf, Riker Laboratories, for their help and support.

\section{References}

1 Nicolaier A. Über die therapeutische Verwendung des Urotropin (Hexamethylentetramin). Deutsch Med Wochenschr 1895;21:541-3.

2 Harding GKM, Ronald AR. A controlled study of antimicrobial prophylaxis of recurrent urinary infection in women. $N$ Engl $\mathcal{Y}$ Med 1974;291:597-601.

3 Petersen S. Long-term prophylaxis with methenamine hippurate in girls with recurrent urinary ract infections. Acta Paediatr Scand 1978;67:597-9.

Cain B B Mus A PM Lack of effect of mo7:597-9. chronic urinary infection. Antimicrob Agents Chemother 1977;12:625-9.

5 Katul MJ, Frank IN. Antibacterial activity of methenamine hippurate. $\mathcal{F}$ Urol 1970;104:320-4.

\title{
Atrial natriuretic peptide concentrations in pre-eclampsia
}

\author{
JØRN KVIST THOMSEN, TOMMY LYAGER STORM, GORM THAMSBORG, \\ MICHAEL DE NULLY, BIRGIT BØDKER, SVEN SKOUBY
}

\begin{abstract}
The concentration of plasma immunoreactive atrial natriuretic peptide is positively associated with right atrial and pulmonary capillary wedge pressure, suggesting that blood volume and hence atrial pressure govern its release. Expansion of plasma volume is a central physiological adjustment in normal pregnancy. Conversely, pregnancies complicated by pre-eclampsia are associated with a reduction in plasma volume and central venous pressure. A study was therefore undertaken to test the hypothesis that plasma atrial natriuretic peptide concentrations are low in pre-eclampsia owing to deficient secretion. Concentrations of the peptide were measured by a specific radioimmunoassay.

The mean plasma immunoreactive atrial natriuretic peptide concentration in healthy pregnant women $(n=22$; third trimester) was higher (56 (1 SD 29) ng/l) than in 25 young, non-pregnant controls $(37(19) \mathrm{ng} / \mathrm{l})$. Concentrations in patients suffering from mild pre-eclampsia $(n=9)$ were higher $(127(60) \mathrm{ng} / \mathrm{l})$ than in
\end{abstract}

Department of Gynaecology and Obstetrics, KAS Herlev, Denmark JøRN KVIST THOMSEN, MD, registrar

MICHAEL DE NULLY, MD, registrar

BIRGIT BØDKER, MD, registrar

SVEN SKOUBY, MD, senior registrar

Department of Medicine, Sundby Hospital, Copenhagen, Denmark TOMMY LYAGER STORM, MD, research fellow GORM THAMSBORG, $M D$, registrar

Correspondence and requests for reprints to: Dr Tommy Lyager Storm, Department of Internal Medicine, Sundby Hospital, 2300 Copenhagen S, Denmark. normal pregnant women, and in patients with severe preeclampsia $(n=6)$ concentrations were higher still $(392(225) \mathrm{ng} / \mathrm{l})$.

Despite failure of plasma volume expansion and low central venous and pulmonary capillary wedge pressures in pre-eclampsia this condition is associated with greatly increased plasma concentrations of plasma immunoreactive atrial natriuretic peptide, which increase still further with the severity of the disease. These findings are clear evidence that atrial pressure may not be the principal determinant of the release of the natriuretic peptide in pre-eclampsia.

\section{Introduction}

The atria of the heart have long been thought to have a role in blood volume control. It has recently been shown that atrial natriuretic peptide is released into the blood by stretching of the atria after expansion of the blood volume. Atrial natriuretic peptide acts on the kidney to promote excretion of salt and water, thus decreasing the extracellular fluid volume and maintaining homoeostasis. ${ }^{1}$ Besides the direct natriuretic and diuretic effects atrial natriuretic peptide inhibits vasoconstriction induced by angiotensin II and noradrenaline and reduces secretion of both renin and aldosterone. ${ }^{2}$

The physiological adjustments in normal pregnancy include an increase in plasma volume, renal plasma flow, and glomerular filtration rate and a decrease in total peripheral resistance. In addition, normal pregnant women are extremely resistant to the pressor effect of infused angiotensin II. ${ }^{3}$ By contrast, in preeclampsia there is a failure of plasma volume expansion ${ }^{4}$ accompanied by salt retention. Renal plasma flow and glomerular filtration rate are less than in normal pregnancy and patients show an increased pressor responsiveness to angiotensin $\mathrm{II}^{s}$ and an increase in 
total peripheral resistance. ${ }^{6}$ Hence, given the known regulatory mechanisms and actions of atrial natriuretic peptide, we might expect to find low concentrations of plasma immunoreactive atrial natriuretic peptide in pre-eclampsia.

In an attempt to test the hypothesis that plasma immunoreactive atrial natriuretic peptide concentrations are low in patients with preeclampsia we have compared these values with those in normal women of the same age.

\section{Subjects and methods}

To establish a normal range of plasma immunoreactive atrial natriuretic peptide concentrations in young women blood was taken from 25 nonpregnant women (mean age 27.6 (range 19-38) years) with no history of preeclampsia or renal or cardiovascular disease. These women were selected at random from the technical staff at the department of clinical chemistry, Sundby Hospital. Blood samples were also drawn from 22 randomly selected normal women in the third trimester of pregnancy (mean age 29.5 (range 19. 37) years) and from 15 consecutive patients (mean age 28.3 (range 21-36) years) with newly discovered pre-eclampsia. All subjects were taking their usual diet and none was receiving any kind of medication other than iron or vitamin supplements. Each patient was investigated shortly after admission. Patients were diagnosed as pre-eclamptic and classified as having mild or severe disease according to criteria of the American College of Obstetricians and Gynecologists.

Atrial natriuretic peptide assay-After at least 30 minutes' rest and with the subjects supine 10-12 ml blood was taken from a peripheral vein into chilled polystyrene tubes containing inhibitors of proteolytic enzymes (disodium edetic acid, aprotinin, and soybean trypsin inhibitor). After centrifugation at $4^{\circ} \mathrm{C}$ each plasma sample was divided into three $0.5-2.0 \mathrm{ml}$ aliquots and 1.5 $6.0 \mathrm{ml} 2.9 \%$ acetic acid added to each. Acidified plasma samples were applied to Sep-Pak $\mathrm{C}_{18}$ cartridges (Waters Associates, Milford, MA, USA), which were prepared by sequential washing with $5 \mathrm{ml}$ methanol and $5 \mathrm{ml}$ distilled water. After being washed with $10 \mathrm{ml}$ distilled water atrial natriuretic peptide was eluted with $2 \mathrm{ml} 80 \%$ ethanol plus $4 \%$ acetic acid. The eluates were reduced to near dryness at $45^{\circ} \mathrm{C}$ by evaporation under nitrogen and lyophilised. Samples were then redissolved and radioimmunoassay of atrial natriuretic peptide done by using specific rabbit anti- $\alpha$ natriuretic polypeptide serum (Peninsula Laboratories). Iodine-125 labelled $\alpha$ atrial natriuretic peptide (human) was used as tracer and synthetic human $\alpha$ atrial natriuretic peptide (1-28) used to construct standard curves: Standards and samples were incubated for 96 hours at $4^{\circ} \mathrm{C}$ in a final volume of $440 \mu \mathrm{l}$. Bound and free ligands were separated by adding dextran coated charcoal. All samples were extracted and assayed in triplicate. Sensitivity of the assay was $5 \mathrm{pg} /$ tube. Intra-assay and interassay variations were $5.9 \%(n=10)$ and $11 \cdot 4 \%(n=9)$, respectively.

Statistical analysis-Data are presented as means and one standard deviation (1 SD). Confidence intervals were calculated on logarithmically transformed data. Comparisons between groups were by the Mann-Whitney $\mathrm{U}$ test. Two sided values of $\mathrm{p}<0.05$ were considered significant.

\section{Results}

Mean ages were similar in all study groups, and the groups of pregnant women did not differ in weight gain or gestational age.

The mean plasma immunoreactive atrial natriuretic peptide concentration in the normal, non-pregnant subjects was $37 \cdot 0(19 \cdot 1) \mathrm{ng} / 1$ (range $7 \cdot 5-85 \cdot 0 \mathrm{ng}$ / l) and in the normal pregnant women 56 (29) $\mathrm{ng} / \mathrm{l}$ (range $21-138 \mathrm{ng} / \mathrm{l}$ ) (ratio of geometric means $1 \cdot 5 ; 95 \%$ confidence interval for ratio of means $1 \cdot 1$ to $2 \cdot 1$; $p<0.02$ ). A substantial overlap into the normal range was seen (figure). The mean concentration in nine patients with mild pre-eclampsia was $127(60)$ $\mathrm{ng} / \mathrm{l}$ (range 62-256 ng/l), which was significantly higher than in normal pregnancy (ratio of geometric means $2 \cdot 3 ; 95 \%$ confidence interval for ratio of means 1.4 to $3.9 ; \mathrm{p}<0.01)$. Compared with the group with mild preeclampsia, however, the six patients with severe disease had still higher values $(392(225) \mathrm{ng} / \mathrm{l})($ range 101-670 ng/l); ratio of geometric means 2.3; $95 \%$ confidence interval for ratio of means 1.5 to $5.9 ; p<0.02$ ). All values were above the normal range (figure).

\section{Discussion}

Factors that regulate atrial natriuretic peptide secretion have not been fully determined. It has been reported that plasma immunoreactive atrial natriuretic peptide concentration is positively asso-

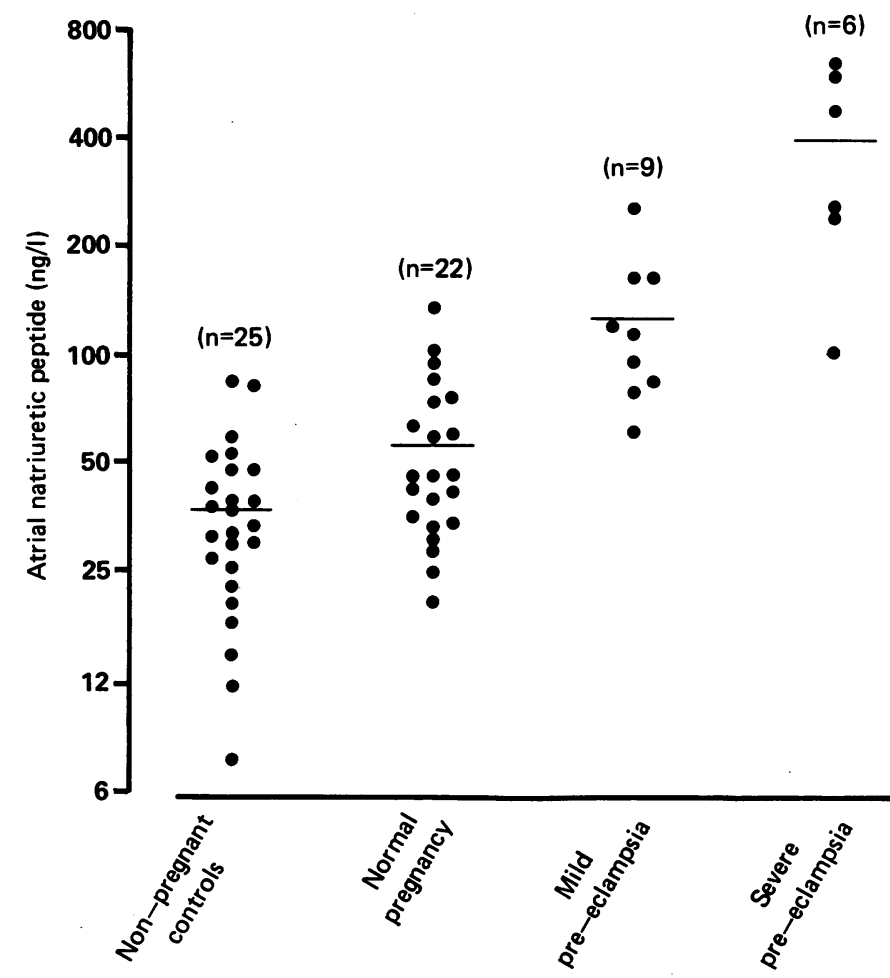

Plasma immunoreactive atrial natriuretic peptide concentrations in normal, pregnant, and pre-eclamptic women. Horizontal bars represent group means.

ciated with atrial pressures ${ }^{8}$ and right ventricular end diastolic pressure $^{9}$ and that atrial natriuretic peptide is released into the bloodstream in man in response to atrial stretch caused by expansion of the blood volume. ${ }^{111}$ These studies suggest that blood volume and hence atrial pressure govern the release of atrial natriuretic peptide.

As atrial natriuretic peptide is concerned in the control of plasma volume and vascular tone we might expect that plasma immunoreactive atrial natriuretic peptide concentrations in pregnant women would differ from those in non-pregnant controls. Our study confirms that concentrations during pregnancy are increased, as they are in animal models. ${ }^{12}$ This may be explained, at least partly, by an increase in blood volume and a concomitant atrial distension. In pre-eclampsia intravascular volume depletion is a prominent feature. This depletion is roughly proportional to the severity of the disease. ${ }^{13}$ In contrast with what might be expected, we found raised concentrations of plasma immunoreactive atrial natriuretic peptide in these patients, with the highest values in those with severe preeclampsia. We can only speculate whether these high plasma immunoreactive atrial natriuretic peptide concentrations are due to reduced metabolic clearance or to increased secretion.

The increased plasma immunoreactive atrial natriurectic peptide concentration in pre-eclamptic subjects may reflect a reduced renal clearance owing to a diminished glomerular filtration rate. This is unlikely, however, as the glomerular filtration rate is only rarely below non-pregnant values. A reduction in metabolic clearance in other tissues remains a possibility.

Another reason for the raised concentrations of plasma immunoreactive atrial natriuretic peptide in pre-eclampsia may be the high blood pressure, as circulating concentrations of the peptide are raised in essential hypertension. ${ }^{14}$ Though most patients with essential hypertension have normal or low blood volume, central venous pressure and pulmonary capillary wedge pressure are usually high. This may explain the increased production of atrial natriuretic peptide in this condition. In contrast, most preeclamptic patients present with low central venous pressure and low pulmonary capillary wedge pressure. ${ }^{15-17}$ Hence it seems surprising that pre-eclampsia is associated with increased plasma immunoreactive atrial natriuretic peptide concentrations.

Our findings show that patients with pre-eclampsia have raised 
concentrations of plasma immunoreactive atrial natriuretic peptide and that concentrations rise further with the severity of the disease. Notwithstanding reports that atrial natriuretic peptide is released into the plasma in response to increased atrial pressure our results imply that this is not the principal stimulus for the raised concentrations of the peptide in pre-eclampsia.

\section{We thank Solveig Petersen for excellent technical help.}

\section{References}

1 Ballermann BJ, Brenner BM. Role of atrial peptides in body fluid homeostasis. Circ Res 1986;58:619-30.

2 Atlas SA, Laragh JH. Atrial natriuretic peptide: a new factor in hormonal control of blood pressure and electrolyte homeostasis. Annu Rev Med 1986;37:397-414.

3 Abdul-Karim R, Assali NS. Pressor response to angiotonin in pregnant and non-pregnant women. Am 7 Obstet Gynecol 1961;82:246-51.

4 Gallery EDM, Hunyor SN, Gyori AZ. Plasma volume contraction: a significant factor in both

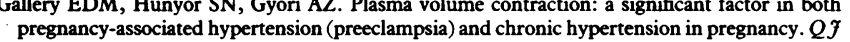
pregnancy-associated hype
Med 1979;48:593-602.

5 Lindheimer MD, Katz AI. Hypertension in pregnancy. N Engl f Med 1985;313:675-80.
6 Assali NS, Vaughan DL. Blood volume in pre-eclampsia: fantasy and reality. Am $\mathcal{F}$ Obstet Gynecol 1977;129:355-9.

7 Pritchard JA, MacDonald PTC, eds. Hypertensive disorders in pregnancy. In: Williams' $\underline{\underline{W}}$ obstetrics. 16th ed. New York: Appleton-Century-Crofts, 1980:665-700.

8 Rodeheffer RJ, Tanaka I, Imada T, Hollister AS, Robertson D, Inagami T. Atrial pressure and secretion of atrial natriuretic factor into the human central circulation. Fournal of the American College of Cardiology 1986;8:18-26.

9 Bates ER, Schenker Y, Grekin RJ. The relationship between plasma levels of immunoreactive atrial natriuretic hormone and hemodynamic function in man. Circulation 1986;73:1155-61.

10 Lang RE, Thölken H, Ganten D, Luft SC, Ruskoaho H, Unger T. Atrial natriuretic factor-a circulating hormone stimulated by volume loading. Nature 1985;314:264-6. 11 Anderson JV, Donckier J, McKenna WJ, Bloom SR. The release of atrial natriuretic peptide in
man. Clin Sci 1985;71:151-5.

12 Kristensen CG, Nakagawa Y, Coe FL, Lindheimer MD. Effect of atrial natriuretic factor in rat pregnancy. Am F Physiol 1986;250:R589-94.

13 Chesley LC. Plasma and red cell volumes during pregnancy. Am $\mathcal{J}$ Obstet Gynecol 1972;112:440-50.

14 Sagnella GA, Shore AC, Markandu ND, MacGregor GA. Raised circulating levels of atrial natriuretic peptides in essential hypertension. Lancet 1986; i: 179-81.

15 Hankins GDV, Wendel GD, Cunningham FG, Leveno KJ. Longitudinal evaluation of hemodynamic changes in eclampsia. Am $\mathcal{J}$ Obstet Gynecol 1984;150.506-12.

16 Clark SL, Greenspoon JS, Aldahl D, Phelan JP. Severe preeclampsia with persistent oliguria: management of hemodynamic subsets. Am f Obstet Gynecol 1986;154:490-4.

17 Groenendiik R, Trimbos JBMJ, Wallenburg HCS. Hemodynamic measurements in preeclampsia preliminary observations. Am $\mathcal{f}$ Obstet Gynecol 1984;150:232-6.

(Accepted 27 March 1987)

\title{
Influence of non-steroidal anti-inflammatory drugs on the outcome of faecal occult blood tests in screening for colorectal cancer
}

\author{
G PYE, K C BALLANTYNE, N C ARMITAGE, J D HARDCASTLE
}

\begin{abstract}
Non-steroidal anti-inflammatory drugs have been accused of causing false positive results in faecal occult blood tests for colorectal cancer. A study was therefore performed in 10931 people undergoing faecal occult blood screening tests to assess the effect of these drugs on the predictive value of a positive test result. Those with a positive result were interviewed and a full drug history was taken before they underwent a full colorectal examination. Of the 455 people with a positive result, 50 were taking non-steroidal anti-inflammatory drugs: $10(20 \%)$ had colonic neoplasia. Of the $\mathbf{4 0 5}$ who were not taking non-steroidal anti-inflammatory drugs, $129(32 \%)$ had colonic neoplasia. These detection rates were not significantly different, and the predictive value of a positive result for an adenoma larger than $1 \mathrm{~cm}$ was $14 \%$ in the group not taking anti-inflammatory drugs and $26 \%$ in the group taking them (not significant).

These results suggest that a finding of occult faecal blood cannot be attributed to upper gastrointestinal tract bleeding caused by non-steroidal anti-inflammatory drugs and should be followed by a thorough colorectal examination.
\end{abstract}

\section{Introduction}

There is much evidence linking the ingestion of non-steroidal antiinflammatory drugs with chronic gastrointestinal bleeding. ${ }^{1}$ These

Department of Surgery, University Hospital, Nottingham NG7 2UH G PYE, MSC, FRCS, Medical Research Council surgical research fellow K C BALLANTYNE, FRCS, Cancer Research Campaign surgical research fellow N C ARMITAGE, DM, FRCS, lecturer in surgery

J D HARDCASTLE, MCHIR, FRCS, professor of surgery

Correspondence to: $\mathrm{Mr}$ Pye. drugs inhibit the synthesis of prostaglandins, which have cytoprotective effects on the upper gastrointestinal tract, as well as suppressing gastric acid secretion. ${ }^{2}$ Testing stool for occult blood is becoming an important means of screening for colorectal neoplasia in individuals over the age of $50,{ }^{3}$ for whom non-steroidal antiinflammatory drugs are widely prescribed. A small study conducted on patients attending a rheumatology clinic suggested that treatment with non-steroidal anti-inflammatory drugs does not lead to false positive faecal occult blood test results, ${ }^{4}$ but another study showed an increase in false positive results in such patients compared with those taking a placebo. ${ }^{5}$ The aim of this study was to establish the effect of ingestion of non-steroidal anti-inflammatory drugs on the predictive value of a positive faecal occult blood test result in population screening for colorectal neoplasia.

\section{Patients, methods, and results}

A total of 10931 asymptomatic individuals (aged 50-74 years) underwent faecal occult blood tests in a screening study for colorectal neoplasia. Either a standard guaiac, pseudoperoxidase based test (Hemoccult) or an immunological test (Feca EIA) was completed over a three or six day period. Individuals with positive faecal occult blood test results were interviewed and a full drug history was taken to establish drug ingestion at the time of the test. They then underwent full colonic assessment either by flexible sigmoidoscopy and double contrast barium enema or colonoscopy.

Of the 10931 individuals who completed the faecal occult blood test, 455 had positive results and underwent full colonic investigation. Fifty of these were taking non-steroidal anti-inflammatory drugs at the time of the test, 10 of whom (20\%) were found to have colonic neoplasia (three carcinomas, seven adenomas more than $1 \mathrm{~cm}$ in size). Of the 405 patients not taking nonsteroidal anti-inflammatory drugs at the time of the test, $129(32 \%)$ had neoplastic disease (23 carcinomas, 106 adenomas more than $1 \mathrm{~cm}$ in size) (table). These detection rates were not significantly different $\left(\chi^{2}=2 \cdot 9\right.$, $\mathrm{p}>0.05)$. The predictive value of a positive test result for a colorectal adenoma more than $1 \mathrm{~cm}$ in size was $14 \%(7 / 50)$ in the group not taking nonsteroidal anti-inflammatory drugs and $26 \%(106 / 405)$ in the group taking them $\left(\chi^{2}=3.5, p>0.05\right)$. 